\title{
Distribution and Occurrence of Desmids in Bhadra Reservoir, Karnataka
}

\author{
Dr. B. R. Kiran \\ Research \& Teaching Assistant in Environmental Science, DDE, Kuvempu University, Karnataka, \\ India
}

\begin{abstract}
Desmid diversity is an important criterion for evaluating the suitability of water for irrigation and drinking purposes. Desmid population of Bhadra reservoir was studied for a period of two years from July 1998 to June 2000. In the present study, a total of 9 genera and 46 species of desmids were recorded and the important genera include Cosmarium with 25 species, Closterium with 3 species, Euastrum (2 species), Staurastrum (11 species), Micrasterias (1species), Desmidium (1 species), Arthrodesmus (1 species), Staurodesmus (1species) and Xanthidium (1 species). With regard to their seasonal occurrence, they were found to be more during summer (58174o/l) and low during rainy season (42016 o/l).
\end{abstract}

Keywords: Bhadra reservoir, desmids, diversity, water quality.

\section{INTRODUCTION}

Phytoplankton is considered as important component of aquatic flora, play a key role in maintaining equilibrium between abiotic and biotic components of aquatic ecosystem (Pandey et al., 2004). Desmids are an order in the Charophyta, a division of green algae that forms a sister group to the land plants (Gontcharov et al., 2003). The desmids are often treated as members of the Zygnematales, as family Desmidiaceae (Kanetsuna, .2002; World Register of Marine Species, 2014). The structure of desmid algae is unicellular, while the cell is sometimes divided into two symmetrical compartments

separated by a narrow bridge or isthmus, wherein the spherical nucleus is located. Each semi-cell houses a large, often folded chloroplast for photosynthesis (https://en. wikipedia.org).

The present study has been carried out to know the diversity and distribution of desmids in Bhadra reservoir of Karnataka. This study is relevant since the present water body forms the source of water for irrigation, drinking, fisheries and for producing hydro electric power.

\section{Materials AND Methods}

\subsection{Study Area}

The location of the study area is depicted in Figure 1. The Bhadra reservoir is located on the Bhadra river a tributary of Tungabhadra river in Chikkamagaluru district in Tarikere Taluk, in the Western part of Karnataka in India. The benefits derived from the reservoir storage are irrigation with gross irrigation potential of 162,818 hectares (402,330 acres) (Bhadhra reservoir project,2011), hydro power generation of 39.2 MW (three powerhouses, located on the right and left bank main canals (Srinivasa Raju \& Nagesh Kumar,2011; "Bhadra dam left bank power house,2011), drinking water supply and industrial use. The dam commissioned in 1965 is a composite earth cum masonry structure of 59.13 metres $(194.0 \mathrm{ft})$ height with length of 1,708 metres $(5,604 \mathrm{ft})$ at the crest level, which submerges a land area of 11,250.88 hectares (27,801.5 acres) (Bhadhra reservoir project,2011; Modernization strategy for Irrigation management: Bhadra Project",2011 ; Harish Kumara et al., 2010 ; (https://en. wikipedia.org/wiki/Bhadra_Dam). 


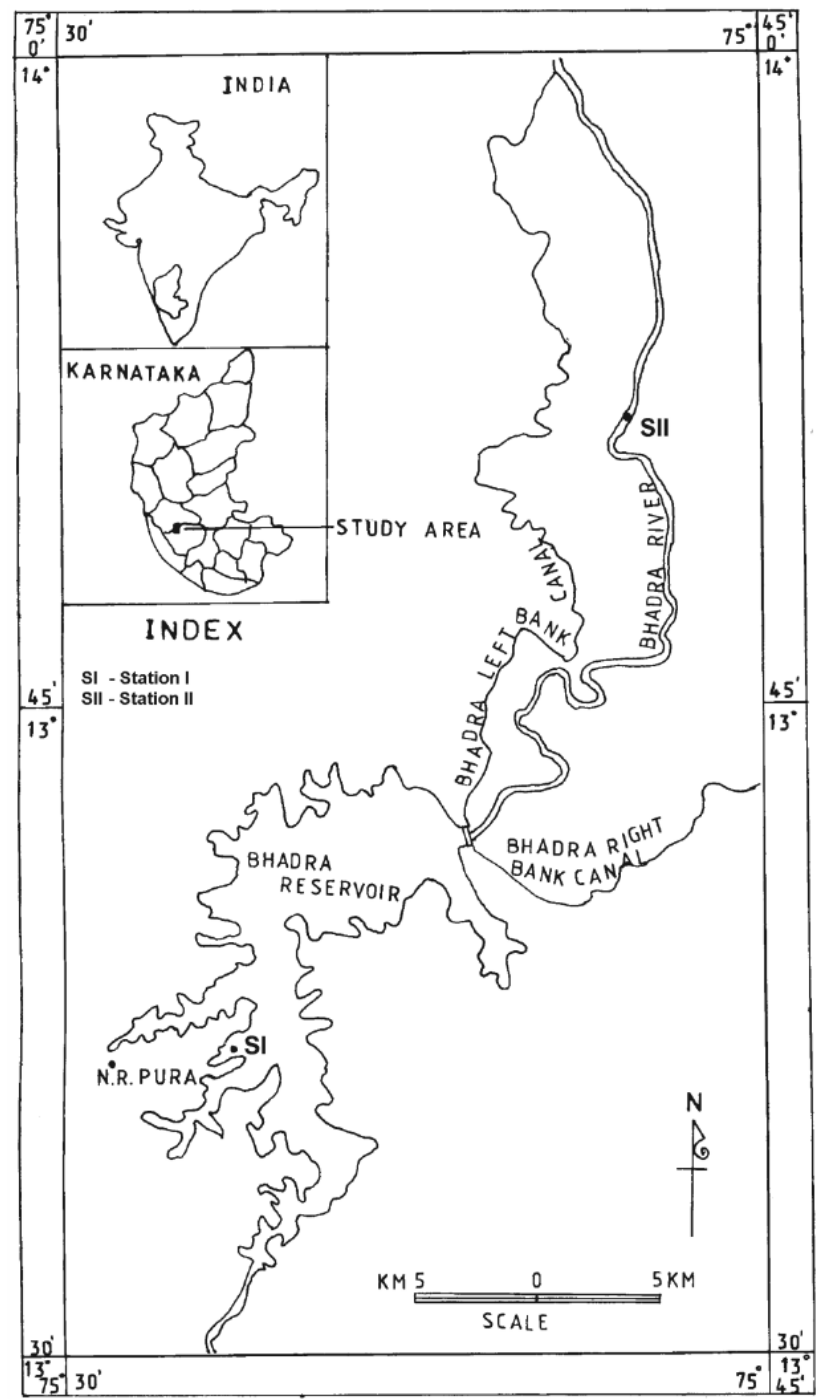

Figure1. A sketch map showing sampling stations of Bhadra reservoir, Karnataka

\subsection{Estimation of Desmids}

Planktonic forms were collected by using plankton net made of bolting silk cloth of meshes of $10 \mu \mathrm{m}$ fixing a glass bottle of $100 \mathrm{ml}$ at a narrow end. For taking the samples of qualitative analysis, the net was towed for 5 minutes just below the surface of water (Green and Holden, 1960). Tows were restricted to a small area around each sampling point. The samples were immediately transferred to other bottles and preserved by adding 4\% formalin as per the practice of Welch (1948). The qualitative estimation was done by taking one $\mathrm{ml}$ of sample from the stock samples at each time and repeated 5 times. Uniform distribution was made by agitating the samples thoroughly. Qualitative identification of desmid organisms was done with the help of monographs and they are identified upto species level (Adoni et al. 1985; Bharathi and Hegde, 1982; Coesel, 1996; Digamber and Vidyavathi, 1985; Hegde and Bharathi, 1985 and Prasad and Mehrotra, 1977).

Further, recorded desmids are appended in Table 1. For the quantitative estimation of desmids a drop of the sedimented sample was taken on a clean slide and a known size of coverslip was put over it. Then the whole coverslip area was scanned under ten different microscopic fields and then the organisms appeared were counted and tabulated as per the Rao's (1953) method.

Table1. List of Desmids recorded in Bhadra reservoir, Karnataka

\begin{tabular}{|c|c|}
\hline Arthrodesmus hiatus & Cosmarium boeckii \\
\hline Closterium lunula & Cosmarium quadrifarium \\
\hline Closterium remarginatum & Cosmarium scabrum \\
\hline Closterium subtrigosum & Cosmarium pseudoconnatum \\
\hline Cosmarium subtumidum & Cosmarium subspeciosum \\
\hline Cosmarium retusiforme & Cosmarium vitiosum \\
\hline \hline
\end{tabular}


Distribution and Occurrence of Desmids in Bhadra Reservoir, Karnataka

\begin{tabular}{|c|c|}
\hline \hline Cosmarium decoratum & Cosmarium striolatum \\
\hline Cosmarium margaritatum & Cosmarium constractum \\
\hline Cosmarium granatum & Cosmarium bioculatum \\
\hline Cosmarium lundelli & Cosmarium depressum \\
\hline Cosmarium contractum & Cosmarium ocellatum \\
\hline Cosmarium spinuliferum & Cosmarium perfissum \\
\hline Cosmarium ordinatum & Cosmarium tumidum \\
\hline Cosmarium moniliforme & Desmidium baileyii \\
\hline Cosmarium corda & Euastrum sublobatum \\
\hline Cosmarium capitulum & Euatrum verrucosum \\
\hline Staurastrum wilde & Micrasterias inciser \\
\hline Staurastrum paradoxum & Staurodesmus hirudinella \\
\hline Staurastrum gracile & Staurastrum sebaldi \\
\hline Staurastrum heterocantha & Staurastrum circulus \\
\hline Staurastrum tohopekaligense & Staurastrum hexacerum \\
\hline Staurastrum longibrachiatum & Staurastrum arachne \\
\hline Staurastrum trilobatum & Xanthidium armatum \\
\hline
\end{tabular}

\subsection{Method of Water Sampling}

Water samples were collected for chemical analysis from Bhadra reservoir at an interval of 30 days. Samples were collected in black plastic carbuoys of 5 litres capacity. For the estimation of certain factors like dissolved oxygen, water samples were taken in $300 \mathrm{ml}$ BOD bottle and fixed immediately using Winkler's reagent. Water temperature and $\mathrm{p}^{\mathrm{H}}$ were recorded at the time of collection. Remaining water quality parameters were estimated as per the standard methods (APHA, 1998).

\section{RESUlts AND DisCuSSION}

A total of 9 genera and 46 species of desmids were recorded (Table 1) during the present study and the important genera include Cosmarium with 25 species, Closterium with 3 species, Euastrum (2 species), Staurastrum (11 species), Micrasterias (1species), Desmidium (1 species), Arthrodesmus (1 species), Staurodesmus (1species) and Xanthidium (1 species). With regard to their seasonal occurrence, they were found to be more during summer (58174o/l) and low (Table 3 and 4) during rainy season (42016 o/l). Figure 2 shows monthly occurrence (o/l) of Desmids in Bhadra reservoir.

Table2. Yearly and two yearly occurrence (o/l) of Desmids in Bhadra reservoir

\begin{tabular}{|c|c|c|}
\hline $\mathbf{1 9 9 8 - 9 9}$ & $\mathbf{1 9 9 9 - 2 0 0 0}$ & $\mathbf{1 9 9 8 - 2 0 0 0}$ \\
\hline 70997.0 & 74501.0 & 145498.0 \\
\hline
\end{tabular}

Table3. Seasonal occurrence of Desmids in Bhadra reservoir during 1998-2000 (o/l)

\begin{tabular}{|c|c|}
\hline Seasons & \\
\hline Rainy & 42016.0 \\
\hline Winter & 45308.0 \\
\hline Summer & 58174.0 \\
\hline Total & $\mathbf{1 , 4 5 , 4 9 8 . 0}$ \\
\hline
\end{tabular}

Table4. Seasonal average of Desmids in Bhadra reservoir (o/l)

\begin{tabular}{|c|c|c|c|}
\hline \multirow{2}{*}{ Seasons } & \multicolumn{3}{|c|}{} \\
\cline { 2 - 4 } & $\mathbf{1 9 9 8 - 9 9}$ & $\mathbf{1 9 9 9 - 2 0 0 0}$ & $\mathbf{1 9 9 8 - 2 0 0 0}$ \\
\hline Rainy & 5397.00 & 5107.00 & 5252.0 \\
\hline Winter & 6083.75 & 5243.25 & 5663.50 \\
\hline Summer & 6268.50 & 8275.00 & 7271.75 \\
\hline Total & $\mathbf{1 7 7 4 9 . 2 5}$ & $\mathbf{1 8 6 2 5 . 2 5}$ & $\mathbf{1 8 1 8 7 . 2 5}$ \\
\hline
\end{tabular}

Among desmids Arthrodesmus hiatus, Coelastrum microporum, Cosmarium subtumidum, C. granatum, C. contractum, C. depressum, C. tumidum, Micrasterias inciser, Staurastrum sebaldi, S. hexacerum, S. arachne, S. heterocantha, S. longibrachiatum, S. trilobatum and Xanthidium armatum occurred in good numbers. While, Desmidium baileyii occurred in less numbers. Hence, Bhadra reservoir is moderately oligotrophic in nature. Sayeswara (2014) recorded 04 genera and 05 species of desmids from Chikkamalappanakere tank of Shimoga district, Karnataka Cosmarium was represented by 2 species. Closteriopsis, Euastrum and Staurastrum was represented by a single species with a 
relative abundance of $11.1 \%$. Patil and Kumawat (2014) reported 36 taxa of desmids from Abhora dam of Maharashtra. Their study deals with the descriptions of 22 taxa of genus Cosmarium corda belonging to 13 species and 09 varieties.

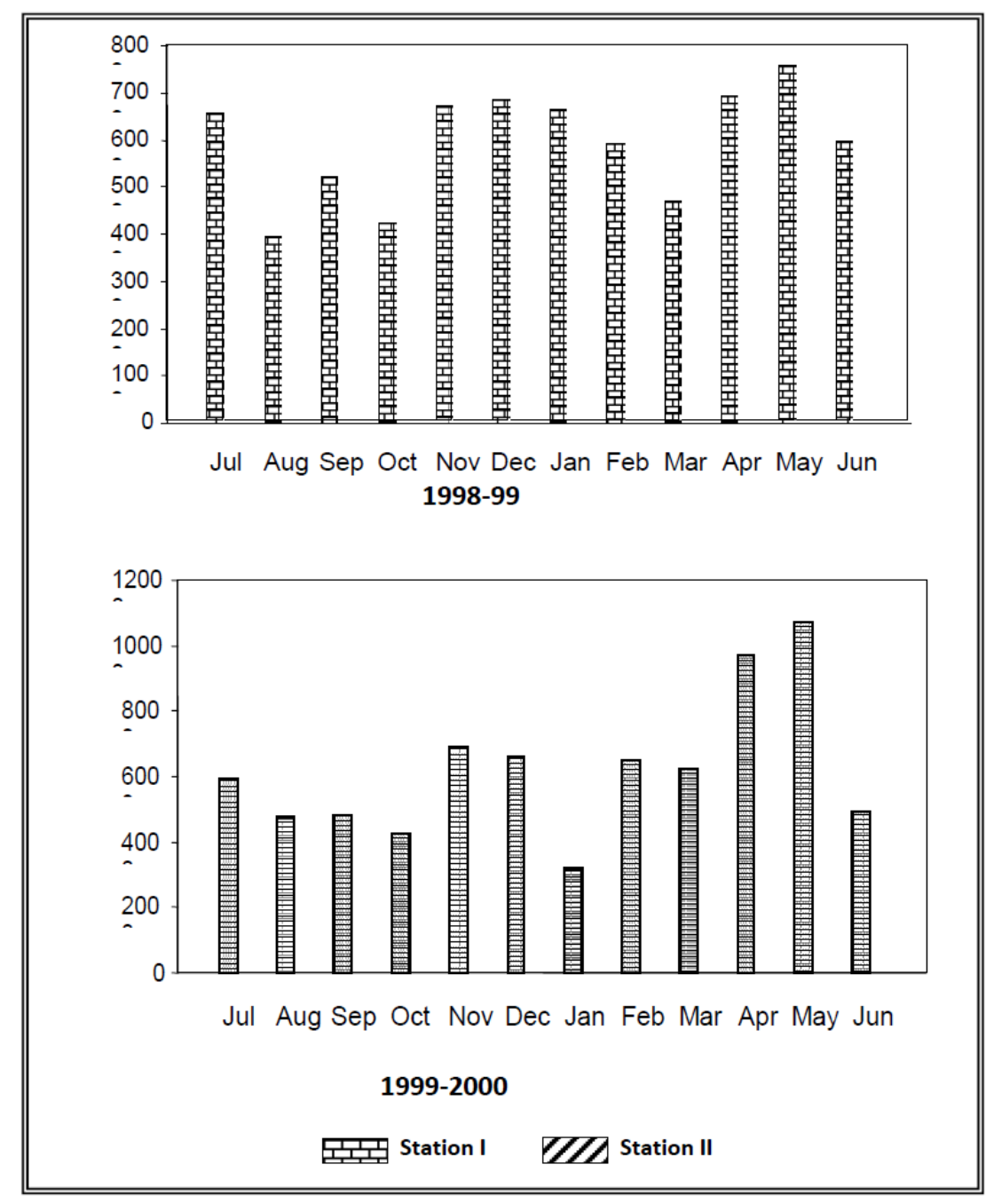

Figure2. Monthly occurrence (o/l) of Desmids in Bhadra reservoir

Zafar (1967) and Pandey and Pandey (1980) have pointed out that the water temperature in the range of $20^{\circ}-30^{\circ} \mathrm{C}$ is favourable for the growth of the desmids. Further, Gonzalves and Joshi (1946) and Zafar (1967) have recorded thicker population of desmids in moderately alkaline waters. Rao (1955) concludes that certain species of desmids are favoured by high $\mathrm{p}^{\mathrm{H}}$ and few by low $\mathrm{p}^{\mathrm{H}}$ and, still others do not show any relationship with $\mathrm{p}^{\mathrm{H}}$. Shashikanth and Anand (1978) correlated high rainfall and turbidity for their minima in the aquatic systems. Nonetheless, a great emphasis is laid on calcium as a factor for their growth and multiplication by Seenayya (1971 b), Mitra (1982), Raj Kumar (1984) and Venkateswarlu (1986).

$\mathrm{p}^{\mathrm{H}}$ was above 7 which contained fairly good number of desmids indicating that the alkaline water supports the desmid population, as corroborated by Gonzalves and Joshi (1946). Shashikanth and Anand (1978) opined that desmids prefer clear and uncontaminated water hence the desmids were nil at lower stretch of Bhadra river as the water is polluted by Industrial effluents and domestic wasters. While, the turbidity values were found to be less and hence harboured desmids, indicating that lower the turbidity values, higher will be the desmid population in Bhadra reservoir. This is an essential agreement with Shashikanth and Anand (1978).

The behavior of desmid towards calcium concentration is rather peculiar. As per Table 5 an average level of calcium $(5.93 \mathrm{mg} / \mathrm{l})$ lodged very high population (Table 4) of desmids $(6062.41 \mathrm{o} / \mathrm{l})$. This finding is in confirmity with Hutchinson and Pickford (1932) who opined that desmid avoid waters with high calcium. While, Munawar (1970) pointed out that desmid respond irregularly towards calcium. 
Distribution and Occurrence of Desmids in Bhadra Reservoir, Karnataka

Table5. Averages of the physico-chemical parameters of Bhadra reservoir

\begin{tabular}{|c|l|c|c|c|}
\hline SI.No & \multicolumn{1}{|c|}{ Parameters } & Average 1998-99 & Average 1999-2000 & $\begin{array}{c}\text { Total } \\
\mathbf{1 9 9 8 - 2 0 0 0}\end{array}$ \\
\hline 1 & Water temperature $\left({ }^{\circ} \mathrm{C}\right)$ & 26.6 & 27.45 & 27.02 \\
\hline 2 & $\mathrm{P}^{\mathrm{H}}$ & 7.46 & 7.46 & 7.46 \\
\hline 3 & Turbidity $(\mathrm{NTU})$ & 7.75 & 7.56 & 7.65 \\
\hline 4 & Electrical conductivity $(\mu \mathrm{m}$ hos/cm) & 66.32 & 61.81 & 64.06 \\
\hline 5 & Total solids $(\mathrm{mg} / \mathrm{l})$ & 249.75 & 324.00 & 286.87 \\
\hline 6 & Total suspended solids $(\mathrm{mg} / \mathrm{l})$ & 206.87 & 288.80 & 247.83 \\
\hline 7 & Total dissolved solids $(\mathrm{mg} / \mathrm{l})$ & 42.88 & 35.19 & 39.03 \\
\hline 8 & Chloride $(\mathrm{mg} / \mathrm{l})$ & 11.21 & 13.59 & 12.40 \\
\hline 9 & Total hardness $(\mathrm{mg} / \mathrm{l})$ & 32.00 & 23.83 & 27.91 \\
\hline 10 & Total alkalinity $(\mathrm{mg} / \mathrm{l})$ & 36.50 & 36.66 & 36.58 \\
\hline 11 & Nitrite $(\mathrm{mg} / \mathrm{l})$ & 0.24 & 0.22 & 0.23 \\
\hline 12 & Ammonia $(\mathrm{mg} / \mathrm{l})$ & 0.008 & 0.015 & 0.011 \\
\hline 13 & Dissolved oxygen $(\mathrm{mg} / \mathrm{l})$ & 7.05 & 6.55 & 6.80 \\
\hline 14 & BOD $(\mathrm{mg} / \mathrm{l})$ & 1.28 & 0.75 & 1.015 \\
\hline 15 & Phosphate $(\mathrm{mg} / \mathrm{l})$ & 0.002 & 0.002 & 0.002 \\
\hline 16 & Calcium $(\mathrm{mg} / \mathrm{l})$ & 5.80 & 6.07 & 5.93 \\
\hline 17 & Magnesium $(\mathrm{mg} / \mathrm{l})$ & 5.40 & 5.69 & 5.54 \\
\hline 18 & Free carbon dioxide $(\mathrm{mg} / \mathrm{l})$ & 8.66 & 9.16 & 8.91 \\
\hline 19 & COD (mg/l) & 2.60 & 2.53 & 2.56 \\
\hline
\end{tabular}

Hegde (1986) has reported desmid from lentic water bodies of Karnataka and concluded that desmids prefer to grow in both in acidic and alkaline waters. He has reported Staurastrum spinipendens from a lentic water body with a $\mathrm{p}^{\mathrm{H}}$ of 4.5 and similarly Staurastrum pseudounicorne in a water body with a $\mathrm{p}^{\mathrm{H}}$ of 8.5 suggesting that desmid occur both in acidic and alkaline waters.

The present work has revealed that phosphate at lower concentration trigger the abundance of desmids. A similar observation has been made by Venkateswarlu (1986). Seenayya (1971 b) is of the opinion that the total solids at higher concentration favour the abundance of desmids. When this is taken into consideration, the content of total solids was high , nevertheless the population of desmid was higher. This observation is quite reverse to the findings of Seenayya (1971 b).

However, Venkateswarlu (1986) is of the opinion that desmids do not show any correlation with that of high or low concentration of total solids. Therefore, our observations are not in essential agreement with that of Venkateswarlu (1986) and Seenayya (1971b).

A large number of workers Zafar (1967), Seenayya (1971b), Rajkumar (1984), Venkateswarlu (1986) have pointed out that the desmids avoid polluted waters. In the present study, downstream stretch of the Bhadra river is highly polluted as it receives the industrial effluent and even a single desmid was not found to grow at this station revealing that desmids do not tolerate the high degree of organic pollution. Hence, the observations made are in essential agreement with that of the above workers.

Desmids are group of phytoplankton that very sensitive to environmental changes and eutrophic conditions are not support their growth (Charles,1955; Edmondson ,1959; Gayathri et al., 2011). Their high density indicates the oligotrophy and free of pollution of the reservoir. Gerrath (1993) reported that desmids are generally more common and diverse in oligotrophic lakes and ponds.

Desmid population was declined during rainy season and recorded the lowest values. This is an agreement with the earlier works of Sukumaran and Das (2001) and Senthilkumar and Sivakumar (2008) .In the present study, among the desmid the genus Cosmarium was the dominant with 25 species. Das et al (2014) recorded 02 species of desmids i.e.,Cosmarium and Closterium from OxBow lake in Nadia district of West Bengal (India).

The low density of plankton during rainy season was due to turbid water, which reduced penetration of sun light and adversely affects the production of plankton. A similar observation was reported by Sugunan et al (2000). In the present study alkaline $\mathrm{pH}$, low levels of calcium, phosphate and turbidity promote the growth of desmids. Continuous monitoring of water is required to know the status of Bhadra reservoir. It suggested a possibility of prediction for desmid variability patterns by some water quality parameters. 


\section{Conclusion}

Desmids did not appear at downstream stretch of Bhadra river. Alkaline waters support luxuriant growth of desmids in the Bhadra reservoir. Water temperature has no bearing on the distribution of desmids, also, high turbidity value do not support the luxuriant growth of desmids. Low phosphate $(0.001 \mathrm{mg} / \mathrm{l})$ encourages their growth. Relatively higher concentration of calcium i.e., above (36.87 $\mathrm{mg} / \mathrm{l}$ ) is not favourable for desmid population. Seasonally, desmids were high during summer and low during rainy season. The data generated clearly revels that the reservoir is basically productive and uncontaminated. Therefore, it is suggested that the status of the reservoir should be maintained by enforcing the environmental protection acts. The catchment area of the reservoir should be protected from the adverse effects of human activities.

\section{RECOMMENDATIONS}

The following recommendations are made for development and Management of the reservoir on scientific lines.

1. The downstream stretch of Bhadra river near Bhadravathi town, where the effluents of Mysore Paper Mills Limited, Visweshwaraiah Iron and Steel Limited and sewage water enters the river, the Desmids were nil. A proper treatment of effluent and sewage is needed at the earliest to improve the quality of water which would certainly help fishes to grow.

2. A small well-equipped field laboratory may be established at Bhadra reservoir for monitoring the hydrobiological parameters and other ecological conditions of the reservoir.

3. The farmers of the adjoining areas of the river system should be informed not to use the chemical fertilizers thereby rendering the river system useful for public. The people living in the areas of the river bank should be kept informed about the impact of environmental degradation and sustainable conservation programmes.

4. It is necessary to develop biological criteria for assessing the quality of water. Hence, attention must be devoted to the critical analysis of the biological data. Field oriented biology is highly desirable at the moment for the real progress on bio-monitoring studies.

5. Awareness among the public about the importance of fishes and water bodies and their sustainable exploitation should be created.

6. It is obvious that, to maintain the healthy conditions of reservoir the catchment area should be protected from the adverse effects of human activities.

\section{ACKNOWLEDGEMENT}

I express my indebtedness and heartfelt thanks to my guide Prof. E.T. Puttaiah, Department of P.G. Studies and Research in Environmental Science, Kuvempu university, Shankaraghatta 577451 for his constant encouragement and able guidance throughout the course of the present investigation.

\section{REFERENCES}

[1] Adoni, A.D., Gunwant Joshi, Kartik ghosh, Chourasia, S.K., Vaishya, A.K., Manoj yadav and Verma, H.G. 1985. Work book on Limnology. Prathiba publishers, Sagar, India.

[2] APHA. 1998. Standard methods for the examination of water and waste water, $20^{\text {th }}$ edition. APHA, AWWA and WEF N.W. Washington. D.C.

[3] Bhadhra Reservoir Project". Water Resources Karnataka: National Informatics Center. Retrieved 17 February 2011.

[4] Bhadra Dam Left Bank Power House". Karnataka Power Corporation. Retrieved 18 February 2011.

[5] Bharati, S.G. and Hegde, G.R. 1982. Desmids from Karnataka State and Goa part III. Genus Cosmarium corda. Nova Hedwigia. Band XXXVI. Braunschweig : 733-757.

[6] Bharati, S.G. and Hegde, G.R. 1983. Desmids of Karnataka state and Goa: Genus Euastrum Ehr. and Micrasterias Agardh. J. Indian bot. Soc. 62: 170-175. 
[7] Charles C.D. (1955) the marine and freshwater plankton. Mishigan State University Press. Mishigan.

[8] Coesel, P. F. M. 1996. Biogeography of desmids. Hydrobiologia 336: 41-53.

[9] Das, S.,Sau,S.K., Das Gupta, M and Trivedi, R.K.2014. Fluctuations of plankton population in Ox-Bow Lake in Nadia district (West Bengal).Journal of Inland Fisheries Society of India 46(1): 76-83.

[10] Digamber, B. and Vidyavathi. 1985. Gibberellic acid effect on Euastrum Verrucosum Ehrenb. J. Indian bot. Soc., 64: 357-361.

[11] Edmondson W.T. (1959) Freshwater biology. University of Washington Seattle. London.

[12] Gayathri N., Rajashekhar M, Kaneez Fatima, Vijaykumar K , Ratandeep and Mahesh Baburrao .2011. Hydrochemistry and plankton diversity of Tungabhadra reservoir Bellary district, Karnataka . International Journal of Zoology Research volume 1 (1):01-07.

[13] Gerrath, J.F. 1993. The Biology of Desmids: a Decade of Progress. In: Round F.E., Chapman D.J. (eds). Progress in Phycological Research. Bristol: Biopress. 79-192.

[14] Gontcharov AA, Marin BA, Melkonian MA (January 2003). "Molecular phylogeny of conjugating green algae (Zygnemophyceae, Streptophyta) inferred from SSU rDNA sequence comparisons". J. Mol. Evol.56 (1): 89-104. Doi:10.1007/s00239-002-2383-4. PMID 12569426.

[15] Gonzalves, E.A. and Joshi, D.B. 1946. Freshwater algae near Bombay. I. The seasonal succession of the algae in a tank at Bandra. J. Bomb. Nat. Hist. Soc., 46: 154-176.

[16] Green, J. and Holden, M.J. 1960. The hydrology and plankton of the river Sokoto. J. Anim. Ecol., 29: 65-84.

[17] Harish Kumara,B.K., S. Srikantaswamy and Shakuntala Bai. 2010. Environmental flows in Bhadra River, Karnataka, India. International Journal of Water Resources and Environmental Engineering Vol. 2(7), pp. 164-173.

[18] Hegde, G.R. 1986. Some noteworthy Desmids from Londa, Karnataka State (India). Hydrobiologia 134: 113-115.

[19] Hegde, G.R. and Bharati, S.G. 1985. Comparative phytoplankton ecology of fresh water ponds and lakes of Dharwad, Karnataka state, India. Proc. Nat. Symp. Pure and Appl. Limnology. (Ed. Adoni, A.D.). Bull. Bot. Soc. Sagar. 32: 24-39.

[20] https://en.wikipedia.org/wiki/Bhadra_Dam.

[21] Hutchinson, G.E. and Pickford, G.E. 1932. Limnological observations on Mountain Lake, Virginia, Int. Revue. Ges. Hydrobiol. Hydrogr., 27 : 25-64.

[22] Kanetsuna, Y. (2002). "New and interesting desmids (Zygnematales, Chlorophyceae) collected from Asia". Phycological Research 50 (2): 101-113. Doi:10.1046/j.1440-1835.2002.00263.x.

[23] Mitra, A.K. 1982. Chemical characteristics of surface water at selected gauzing stations in the river Godavari, Krishna, Tungabhadra. Indian J. Environ. Hlth., 24 : 165-179.

[24] Modernization Strategy for Irrigation Management: Bhadra Project" (PDF). Fao. Org. pp. 8-11. Retrieved 19 February 2011.

[25] Munawar, M. 1970. Limnological studies on freshwater certain polluted and unpolluted environments. Hydrobiol., 39(1) : 105-128.

[26] Pandey B N, Hussain S, Ambasta O P and Podar S K (2004), "Phytoplankton and its correlation with certain physico-chemical parameter of Ramjan river of Krishaganj, Bihar", Environment \& Ecology, Vol. 22, pp. 804-809.

[27] Pandey, U.C. and Pandey, D.C. 1980. Desmids of Allahabad I. J. Indian Bot. Soc., 59: 246-250.

[28] Patil S.B. and Kumawat D.A.2014. Diversity of genus Cosmarium corda from Abhora Dam of Jalgaon district, Maharashtra. International Journal of Geology, Earth and Environmental Sciences Vol. 4 (1) January-April: .109-114.

[29] Prasad, B.N. and Mehrotra, R.K. 1977a. Some Desmids new to Indian flora. J.Indian bot. Soc., 56:343-350.

[30] Prasad, B.N. and Mehrotra, R.K. 1977b. Desmid flora of North India paddy fields. New Botanist 4: 49-74. 
[31] Rajkumar, B. 1984. Ecological studies in the river Manjira with special reference to its lithophytic flora. Ph.D. Thesis. Osmania University, Hyderabad.

[32] Rao, C.B. 1953. On distribution of algae in a group of six small ponds. J. Ecol., 41: 62-71.

[33] Rao, C.B. 1955. On distribution of algae in a group of six small ponds. II. Algal periodicity. J. Ecol., 43: 291-308.

[34] Sayeswara, H.A. 2014. Phytoplankton species diversity in Chikkamalappanakere tank, Shivamogga, Karnataka, India. Int. J. LifeSc. Bt \& Pharm. Res. Vol 3(4): 98-102.

[35] Seenayya, G. 1971b. Ecological studies in the plankton of Certain freshwater ponds of Hyderabad, India. II. Phytoplankton. Hydrobiol., 37 : 55 -88.

[36] Senthilkumar, R. and Sivakumar, K. 2008. Studies on phytoplankton diversity in response to abiotic factors in Veeranam Lake in the Cuddalore district of Tamil Nadu physicochemical parameters. J.of Environ. Biol.29 (5): 747-752.

[37] Shashikanth and Anand, V.K. 1978. Interrlationships of Phytoplankton and physical factors in Mansar lake Jammu (J \& K). Indian J. Ecol., 5(2): 134 - 140.

[38] Somashekar, R.K. 1987. Phytoplankton composition of river Cauvery. J. Ecol. Env. And Cons., 6: 132-137.

[39] Srinivasa Raju \& Nagesh Kumar. 2011. Multicriterion Analysis In Engineering And Management. PHI Learning Pvt. Ltd. pp. 194-195.ISBN 978-81-203-3976-7. Retrieved 18 February 2011.

[40] Sugunan,V.V.,Vinci,G.K.,Bhattacharjya, B.K.and Hassan, M.A.2000.Ecology and Fisheries of Beels in West Bengal.Bull.No.Nov.,103, CIFRI,Barrackpore.

[41] Sukumaran, P.K. and Das, A.K. 2001. Distribution of plankton in some freshwater reservoirs of Karnataka. J. Inland. Fish. Soc. India. 33: 29-36.

[42] Venkateswarlu, V. 1986. Ecological studies on the rivers of Andhra Pradesh with special reference to water quality and pollution. Proc. Indian Acad. Sci. Plant Sci., 96: 495-508.

[43] Welch, P.S. 1948. Limnological methods, Balkistan philadelphia, U.S.A: 281-381.

[44] World Register of Marine Species". Retrieved 18 September 2014.

[45] Zafar, A.R. 1967. On the ecology of algae in certain fish ponds of Hyderabad, India III. The periodicity. Hydrobiologia 30: 96-112. 